\title{
METHODICAL APPROACHES TO ASSESSMENT OF THE IMPACT OF THE REPUTATION CAPITAL ON INVESTMENT PROCESSES IN THE REGION (ON THE EXAMPLE OF REGIONS OF THE VOLGA FEDERAL DISTRICT)
}

\author{
Marat Rashitovich Safiullin $^{{ }^{*}}$, Alexander Stanislavoich Grunichev ${ }^{2}$, Leonid Alekseevich Elshin ${ }^{3}$
}

${ }^{1}$ State Budgetary Institution Center on Perspective Economic Researches, Academy of Sciences, Republic of Tatarstan,

Kazan Federal University, Russia, ${ }^{2}$ Kazan Federal University, Russia, ${ }^{3}$ State Budgetary Institution Center on Perspective Economic Researches, Academy of Sciences, Republic of Tatarstan, Kazan National University of Science and

Technology, Russia.

Email: *marat.safiullin@ tatar.ru

Article History: Received on $24^{\text {th }}$ August 2019, Revised on $25^{\text {th }}$ September 2019, Published on $29^{\text {th }}$ October 2019

\begin{abstract}
Purpose: In the paper, the need to study models of economic growth in territories in terms of the reputational economy theory is substantiated. The issue is relevant due to the fact that in modern conditions when economic development institutions are being transformed, primarily as a result of globalization of economic processes, the regional reputational capital begins to play an increasingly prominent and significant role.

Methodology: The authors build the time series of the studied indicator for the regions of the Volga Federal District for the period of 2010-2017 based on the developed methodology for the formalized assessment of a territory's reputation. Econometric assessments of a territory's reputational capital influence on the parameters of their investment activity are carried out on the basis of those time series. The developed and tested methodological tools for quantitative assessment of the region's reputational capital form a stable basis for conducting research activities aimed at a multifactorial analysis of the key components determining the territory's reputation.
\end{abstract}

Result: This, in turn, forms stable preconditions for determining and system analysis of the development prospects of a competitive interregional environment and also forms the basis for the implementation of economic and mathematical assessments aimed at determining the impact of a territory's reputation on key parameters of its socio-economic development.

Applications: This research can be used for universities, teachers, and students.

Novelty/Originality: In this research, the model of Methodical approaches to the assessment of the impact of the reputation capital on investment processes in the region is presented in a comprehensive and complete manner.

Keywords: reputational capital of a region, reputational economy, investment activity, quantitative assessment of a region's reputation, globalization, factors of economic growth, econometric modeling.

\section{INTRODUCTION}

As a practice and empirical observations show, the reputational activity of economic agents forms a whole set of prospects for their development conditioned by stable positive or, on the contrary, negative expectations of counterparties interacting with them regarding the opportunities of their own development, both in conjunctural and institutional aspects. In this regard, reputation is very important and is becoming widespread in the scientific research field. Meanwhile, it should be noted that the study of the question posed in the space of scientific works and research mainly concentrates at the microlevel (Arslan \& Seker, 2014; Dorčák, Markovič, \& Pollák, 2017; Villalobos, Márceles, \& Ayala, 2013; Villalobos, 2018). That is, the vast majority of works are devoted to the study of the reputation of firms as one of the most important "representatives" of economic agents. At the same time, the study of reputational capital and its influence on the development of regional/national economic systems is unfairly ignored. At the same time, it is necessary to state that in recent years the attention of scientists begins to be more and more concentrated on the problems set above (Manaman, Jamali, \& AleAhmad, 2016; Ji, Li, North, \& Liu, 2017; Dorčák, Markovič, \& Pollák, 2017). However, the theory of the territories' reputational economy has not been developed as it is necessary and has not received due attention yet; this largely limits the research paradigm based on the study of intangible production factors in the system of socio-economic development of regions or national economic systems in general.

Formalized approaches to assessing the reputational capital of a region, its impact on the parameters of the socio-economic development of territories in the context of an actively transforming institutional and business environment are a multilevel complex task. Its solution will largely contribute not only to the development of comprehensive and generally accepted methodologies (tools) for diagnosing the reputation of economic systems at the meso- and macro-level, but also to update methods for modeling and forecasting them in terms of intangible factors of production, which importance in recent decades has become increasingly important in the system of macroeconomic transformations.

\section{METHODS}

The assessment of the region's reputational capital is based on 5 key sub-indices (Figure 1). 


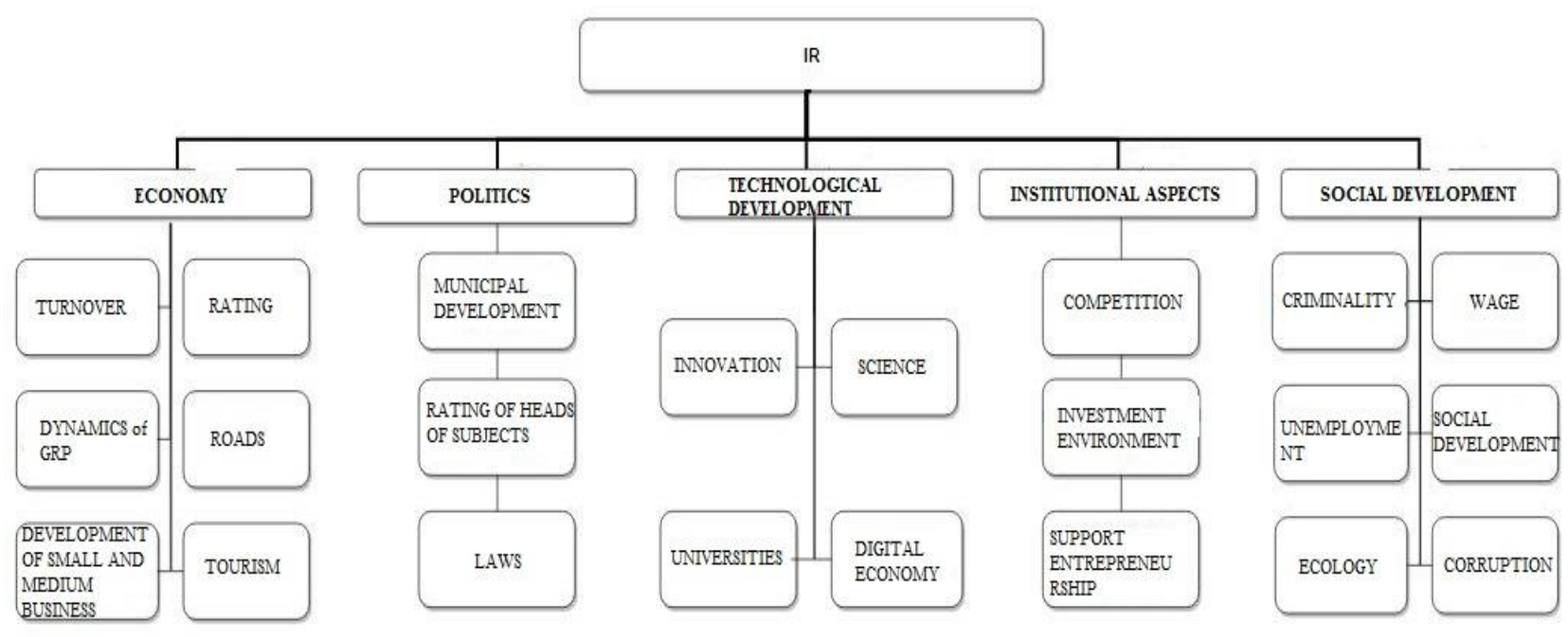

Figure 1: The system of search queries that form the visions (image) of the territory's (region's) reputation

The basis of the algorithm for calculating the values of the sub-indexes to evaluate a particular aspect of the region's reputation involves the implementation of a series of iterations.

Iteration 1: Identification of the wording for search queries that reveal the image and potential of the region.

Iteration 2: Determining the popularity of the query in the external environment. This stage of the study involves an assessment of the tonality for information search results, taking into account the information source level (federal/regional media), as well as the probability of following a corresponding link. The implementation of this procedure is carried out in the context of the search engines (Google, Yandex, Mail.ru, etc.) under analysis. In a structured form, the implementation process of the considered iteration can be represented as table 1. Pugacheva, A. S., Filippova, V. P., Kon, A. Y., Dorzhieva, L. B., Silchenok, I. S., Pugacheva, N. B., ... \& Mustafina, A. A. (2016).

Table 1: An example of determining the popularity of a query in the external environment

\begin{tabular}{lllll} 
Line number & Probability of following the link & Tonality & Source level $*$ & Actual place in query results \\
\hline 1 line & $26.90 \%$ & + & 1 & \\
\hline 2 line & $17.10 \%$ & - & 1 & 1 \\
\hline 3 line & $14.90 \%$ & - & 1 & 2 \\
\hline 4 line & $8.90 \%$ & + & 1 & 7 \\
\hline 5 line & $7.10 \%$ & + & 2 & 8 \\
\hline 6 line & $4.70 \%$ & + & 1 & 9 \\
\hline 7 line & $5.60 \%$ & - & 1 & 10 \\
\hline 8 line & $5.10 \%$ & + & 2 & 12 \\
\hline 9 line & $4.70 \%$ & + & 1 & 15 \\
\hline 10 line & $4.70 \%$ & + & 1 & \\
\hline
\end{tabular}

*1 - the federal source of information; 2 - regional source of information.

Iteration 3: In the context of each search engine participating in the procedure on analyzing the region's reputation capital, the coefficient "The popularity of the query in the external environment $\left(\mathrm{K}_{\mathrm{qp}}\right)$ is estimated according to formula 1.

$K q p=\mathrm{Z} P_{j} \times I_{j}$

$\mathrm{K}_{\mathrm{qp}}$ - The coefficient of the popularity of the query;

$\mathrm{j}$ is the query number;

$P_{j}$ - The probability of clicking the $j$-th row of the query result;

$I_{j}$ - The level of information source (federal/regional).

The range of possible values of the coefficient, taking into account the basic algorithm, varies from $-1,994$ to $+1,994$. 
Iteration 4: Assessment of the region's reputational capital with use of the search query (Determination of the reputation of a query in RuNet (within search engines: Google, Yandex, Mail.ru, etc.).

The calculation of the values of this indicator is carried out according to formula 2 Simonova, M. V., Sankova, L. V., Mirzabalaeva, F. I., Shchipanova, D. Y., \& Dorozhkin, V. E. (2016).

$K_{r a}=\sum T_{k} \times K_{n} \times V i$;

Where

$\mathrm{K}_{\text {ra }}$ - Reputational activity coefficient for the region according to the search query;

$\mathrm{T}_{\mathrm{k}^{-}}$- The tonality of the search engine;

$\mathrm{K}_{\mathrm{p}}$ - The popularity of the query;

$\mathrm{Vi}$ - The search engine share in RuNet.

The tonality of a search engine is understood as a system of assessments related to the analyzed subject of the region's reputational activity, which is determined based on an analysis of positive and negative assessments of the search query. With this, the value of the coefficient $\mathrm{T}_{\mathrm{k}}$ is determined according to formula 3 Pugacheva, A. S., Filippova, V. P., Kon, A. Y., Dorzhieva, L. B., Silchenok, I. S., Pugacheva, N. B., ... \& Mustafina, A. A. (2016).

$\mathrm{T}_{\mathrm{k}}=\left(\mathrm{T}_{+\mathrm{i}}-\mathrm{T}_{-\mathrm{i}}\right) / 10$

Where

$\mathrm{T}_{+\mathrm{i}}$ - The number of positive assessments given for a search query in the analyzed search engine;

$\mathrm{T}_{-i}$ - The number of negative assessments given for a search query in the analyzed search engine;

i - The number of search engines involved in the study.

The value in the denominator (10) is determined by the number of search engine responses to the query being analyzed and included in the analytical database. As it is previously mentioned, the inclusion in the analysis of the number of responses to a query in excess of 10 is not advisable due to the low probability of their click by users (less than 3-5\%).

The most important component involved in formula 3 is the index characterizing the search engine share in RuNet. A kind of this index acts as a weighting factor and demonstrates the role of one or another search engine in determining the values of the region's reputation capital within the framework of a single search query Simonova, M. V., Sankova, L. V., Mirzabalaeva, F. I., Shchipanova, D. Y., \& Dorozhkin, V. E. (2016).

Iteration 5: Calculation (quantitative assessment) of the sub-index characterizing a particular aspect of the region's reputation capital.

The assessment of the value of the indicator is carried out as the sum of products of weighted coefficients of the region's reputational activity. Formula definition of sub-indices is as follows:

$I_{r_{i}}=\sum$ Kra $\times w_{i}$

Where

$\mathrm{I}_{\text {ri }}$ - Aggregated sub-index of a region's reputational activity;

Kra - Coefficient of the region's reputational activity for a search query

$\mathrm{W}_{\mathrm{i}}$ - Share of requests to the query in RuNet within the analyzed number of search queries. It is determined on the basis of statistics of queries (Aivazian, Bereznyatsky, \& Brodsky, 2017; Shlyapentokh, 1966).

$\mathrm{i}$ - The number of sub-indices participating in the study.

Iteration 6: The calculation of the integral index of the region's reputational activity.

$R=\sum \ln i \times w_{i}$

Where

$I_{\text {ri }}$ - Aggregated sub-index of the region's reputation activity;

$\mathrm{W}_{\mathrm{i}}$ - The value of the weighting factor defined as the proportion of the number of hits for the search query to the sum of users hits for the queries analyzed in the study.

The most important methodological aspect being formed within the framework of the developed concept of research on the territory's reputational capital is the factor analysis of the weighting factors for the subindexes that form the basis for calculating the integral index for the territory's reputational capital. Their accounting and assessment determine a wide 
range of functional analysis which allows revealing which components and to what extent form the dynamics and quality of the territory's reputation capital Simonova, M. V., Sankova, L. V., Mirzabalaeva, F. I., Shchipanova, D. Y., \& Dorozhkin, V. E. (2016).

\section{RESULTS AND DISCUSSION}

Based on the above tools, the integral values of the reputation capital index for the Republic of Tatarstan for the period from 2010 to 2017 were obtained as a result of the estimates and calculations implemented (Table 2, Figure 2).

Table 2: Dynamics of the reputation capital index for the Republic of Tatarstan $\left(\mathrm{I}_{\mathrm{RC}}\right)$ and the main components determining its level

\begin{tabular}{|c|c|c|c|c|c|c|c|c|}
\hline Subindexing & $\stackrel{0}{\circ}$ & $\bar{\sigma}$ & $\frac{\text { ก }}{2}$ & $\frac{m}{2}$ & 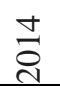 & $\frac{n}{0}$ & $\frac{0}{0}$ & 긍 \\
\hline Region's reputation in the field of economics & 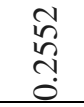 & $\begin{array}{l}0 \\
\text { N1} \\
0\end{array}$ & 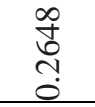 & 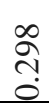 & $\mathfrak{n}_{0}^{n}$ & 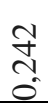 & กิ & గి \\
\hline $\begin{array}{l}\text { Region's reputation in the field of social } \\
\text { development }\end{array}$ & $\frac{⿱}{ָ}$ & 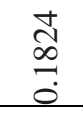 & $\frac{\dot{\sigma}}{\stackrel{\sigma}{0}}$ & 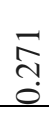 & $\begin{array}{l}\text { స̦ } \\
\text { on }\end{array}$ & $\frac{1}{2}$ & 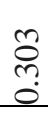 & $\stackrel{n}{n}$ \\
\hline $\begin{array}{l}\text { Region's reputation in the political } \\
\text { (managerial) development }\end{array}$ & $\underset{0}{\stackrel{J}{0}}$ & $\begin{array}{l}0 \\
\stackrel{0}{0} \\
0\end{array}$ & $\stackrel{2}{2}$ & $\stackrel{\infty}{8}$ & 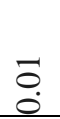 & $\begin{array}{l}\overline{0} \\
0\end{array}$ & $\begin{array}{l}8 \\
8 \\
0\end{array}$ & $\begin{array}{l}n \\
8 \\
0\end{array}$ \\
\hline $\begin{array}{l}\text { Region's reputation in the technological } \\
\text { development }\end{array}$ & $\stackrel{n}{=}$ & $\stackrel{\Xi}{\Xi} 6$ & $\stackrel{m}{=}$ & $\begin{array}{l}\infty \\
\stackrel{0}{0} \\
\dot{0}\end{array}$ & $\begin{array}{l}\infty \\
\stackrel{\infty}{\circ} \\
\dot{0}\end{array}$ & $\frac{N}{0}$ & $\begin{array}{l}0 \\
\infty \\
0 \\
0 \\
0\end{array}$ & $\stackrel{0}{0}$ \\
\hline Institutional Aspects of the region's reputation & $\stackrel{n}{\tilde{0}}$ & $\stackrel{\infty}{\stackrel{\infty}{\sigma}}$ & 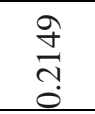 & $\begin{array}{l}0 \\
0 \\
0\end{array}$ & 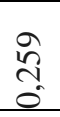 & $\underset{0}{\nabla}$ & $\stackrel{\overbrace{}}{0}$ & ֻே \\
\hline
\end{tabular}

Integral value of the region's reputation capital index
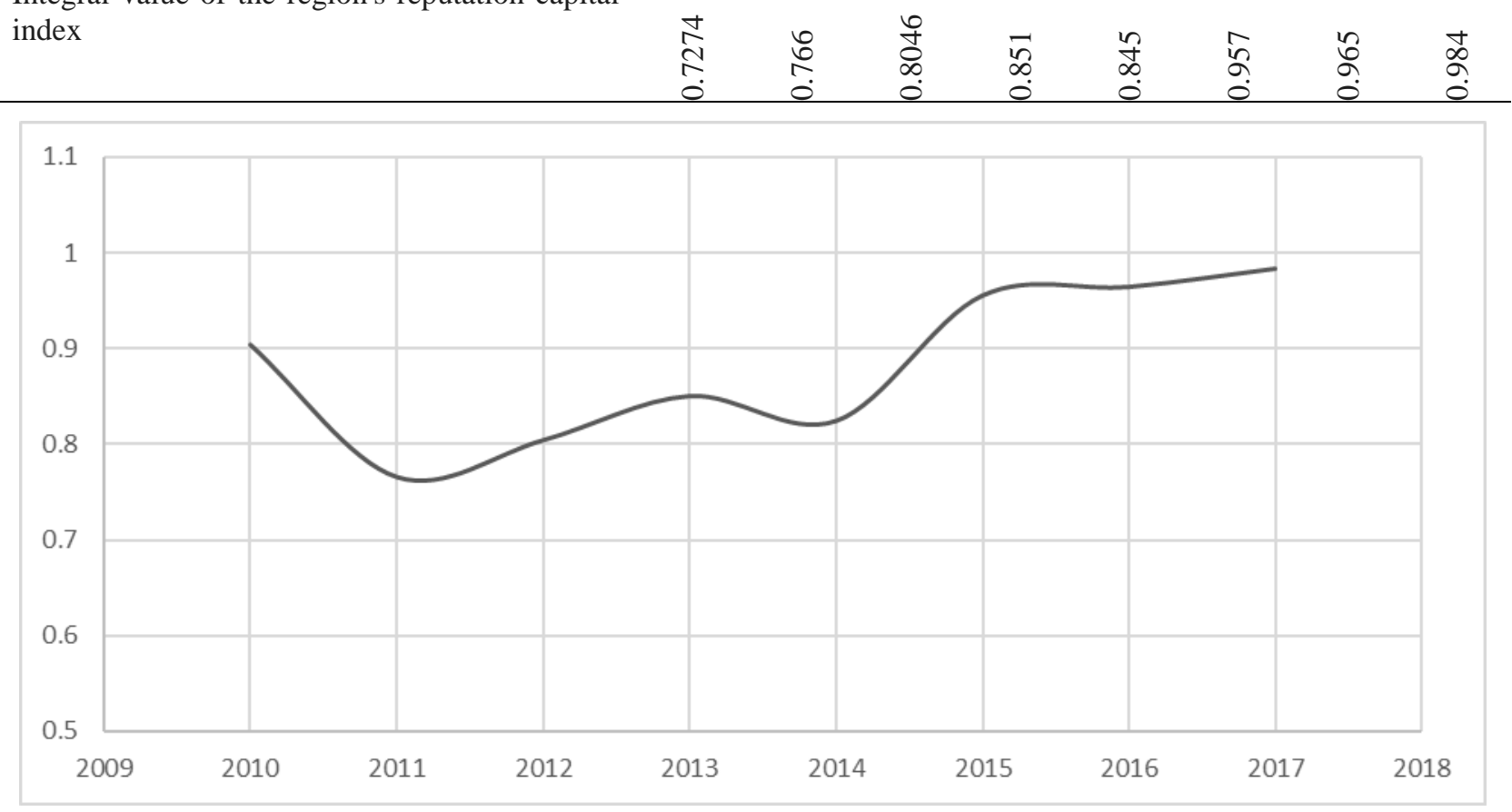

Figure 2: Dynamics of the reputational capital of the Republic of Tatarstan $\left(\mathrm{I}_{\mathrm{RC}}\right)$ and the main components determining its level

The obtained estimates of the dynamic component "Territory's Reputational Capital Index" make it possible to proceed to the most important stage of the study: identifying the relationship between the level of the region's reputation capital and the parameters of its socio-economic development. Methods of econometric modeling were chosen as a tool to help to solve the question posed, where the Reputational Capital Index is used as an exogenous variable, and aggregated economic development indicators recorded by the statistical authorities are the endogenous variables. The main hypothesis here suggests that the region's reputation is a kind of resource (intangible asset) that contributes not only to the sustainable 
development of the territory but also to the intensification of business and economic activity based on the intensification of the investment activities of economic entities.

Guided by the principles and tools of the dummy variable's method, dummy variables were step by step added to the original model in order to increase the statistical significance of the resulting models.

As a result of these iterations, the regression model acquired the following form (1):

$\mathrm{I}_{\%}=-1.32+0.99 \mathrm{I}_{\mathrm{RC}}+1.52 \mathrm{~F} 1+1.05 \mathrm{~F} 2$

Where:

$\mathrm{I} \%$ - The growth rate of investment in fixed assets, in \% of the previous year;

$\mathrm{I}_{\mathrm{RC}}$ - Integral index of the region's reputational activity;

F1, F2 - Dummy variables.

The obtained parameters which characterize the statistical significance of the obtained regression model with two dummy variables, demonstrate its very high level of confidence $\left(\mathrm{R}^{2}=0.81 ; p\right.$ - values criteria are less than the specified level of significance equal to 0.05 )

The presented estimates and calculations demonstrate a high level of verification of the constructed model. This allows us to form an evidence base that there is a unique relationship between the level of the object's reputational activity and the parameters of its socio-economic development Pugacheva, A. S., Filippova, V. P., Kon, A. Y., Dorzhieva, L. B., Silchenok, I. S., Pugacheva, N. B., ... \& Mustafina, A. A. (2016).

The result obtained allows us to proceed to the most important stage of the study: the search and determination of the closeness of the relationship between the indicators under consideration at the level of other regions. Using the developed methodological tools tested successfully by the example of one of the regions, namely, the Republic of Tatarstan, estimates were made regarding the parameters of the relationship between reputational activity and investment activity dynamics at the level of other regions of the Volga Federal District.

In accordance with them, a series of regression models were built for each region under study in accordance with the principles outlined above in the framework of modeling interconnections exemplified by the Republic of Tatarstan. The results demonstrating the values of the coefficients at the reputational capital index of each region ( $\left.\mathrm{I}_{\mathrm{RC}}\right)$ are presented in table 6, figure 3 .

Table 6: Values of regression model coefficients with exogenous factor $\left(\mathrm{I}_{\mathrm{RA}}\right)$ assessing the regional reputation capital influence on the dynamics of investments in fixed capital (in decreasing order)

\begin{tabular}{lll}
\hline No & Region & Coefficient value at $\mathrm{I}_{\mathrm{RK}}$ \\
\hline 1 & Nizhny Novgorod Region & 1,121 \\
\hline 2 & Perm region & 1,058 \\
\hline 3 & Samara Region & 1,056 \\
\hline 4 & Republic of Bashkortostan & 1,005 \\
\hline 5 & Republic of Tatarstan & 0.991 \\
\hline 6 & Republic of Mordovia & 0.852 \\
\hline 7 & Saratov region & 0.787 \\
\hline 8 & Republic of Udmurtia & 0.683 \\
\hline 10 & Kirov region & 0.667 \\
\hline 11 & Penza region & 0.651 \\
\hline 12 & Chuvash Republic & 0.628 \\
\hline 13 & Orenburg region & 0.611 \\
\hline 14 & Ulyanovsk region & 0.567 \\
\hline
\end{tabular}

\section{SUMMARY}

In general, it should be noted that reputational capital plays a significant role in the process of socio-economic development of regions, as evidenced by the calculations obtained. Meanwhile, the significance of this factor is much differentiated, which can be clearly seen in the example of the presented calculations (table 6).

It is important to note that reputation has a more noticeable impact in regions with higher parameters of socio-economic development. This may be due to the effect expressed in the fact that the regions of this type have a high level of potential and opportunities for development. Taking into account the fact that, in accordance with our interpretation, the territory's reputational capital is a consequence of the set of opportunities it provides for the efficient development of business entities, the conclusion obtained quite fits into the boundaries of the logic outlined. At the same time, possessing special 
means and methods capable of increasing the level of the region's reputational activity in the information space, additional tools and opportunities open up to intensify socio-economic development. This effect will be reflected in the growth of business and economic activity.
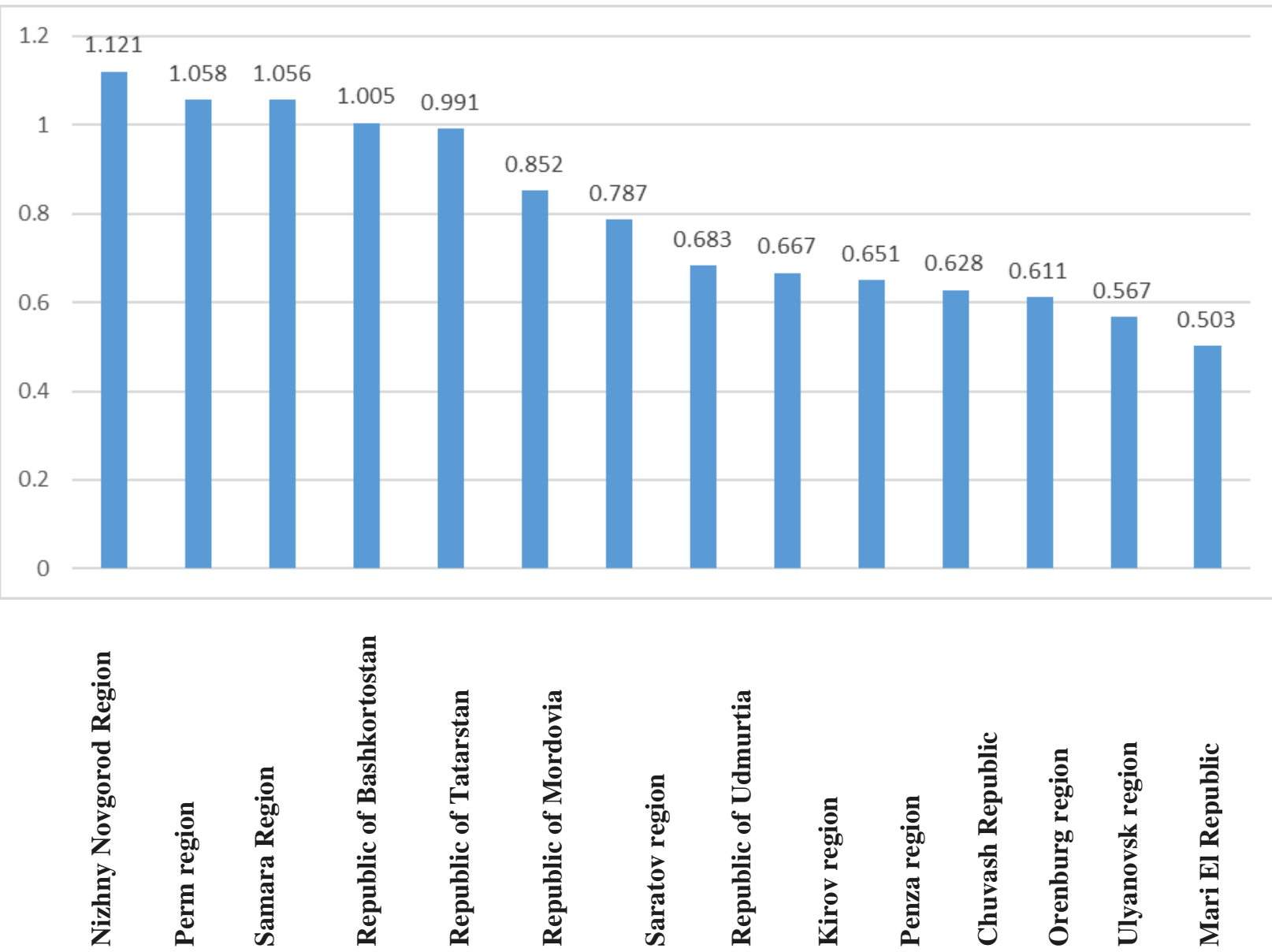

Figure 3: Values of regression model coefficients with exogenous factor $\left(\mathrm{I}_{\mathrm{RC}}\right)$ evaluating the region's reputational capital (in descending order)

\section{CONCLUSION}

Making the subtotal for the results obtained, which reveal a quantitative assessment for the generation of reputational capital in the regions (using the example of the Volga Federal District), it should be noted that the reputation building process consists of a number of components ("blocks"). Moreover, each of them has not only its own level but also a certain "weight" which largely determines the contribution of a component to the process of formation of the territory's reputational capital. It is also important to note that the differentiation revealed in the course of the study determines the reputational capital indices in the regions of the Volga Federal District, forms a kind of understanding of the processes and phenomena under study, but creates a stable basis for developing and adopting public policy measures aimed at creating an advantageous image and regions' reputations. This is important both from the point of view of social attractiveness and from the point of view of intensifying the process of economic development. The latter thesis is due to the fact that the reputation of any business entity (including a region, being adhered to the position that it acts as a quasi-corporation) determines the development potential of economic agents and their expectations regarding their future. This, in turn, forms the preconditions for the revitalization of business and economic activity in regions with a high level of reputational capital and, as the study showed, the activation of investment processes.

\section{ACKNOWLEDGMENTS}

The work is performed according to the Russian Government Program of Competitive Growth of Kazan Federal University.

The publication was prepared within the framework of the research project No. 19-010-00211 supported by the Russian Foundation for Basic Research (RFBR)

\section{REFERENCES}

1. Aivazian, S., Bereznyatsky, A., \& Brodsky, B. (2017). Macroeconomic modelling of the Russian economy. 
Applied Econometrics, Publishing House "SINERGIA PRESS", 47, 5-27.

2. Arslan, M. L., \& Seker, S. E. (2014). Web based reputation index of Turkish universities. arXiv preprint arXiv:1401.7547. https://doi.org/10.7763/IJEEEE.2014.V4.330

3. Dorčák, P., Markovič, P., \& Pollák, F. (2017). Multifactor analysis of online reputation of selected car brands. Procedia engineering, 192, 719-724. https://doi.org/10.1016/j.proeng.2017.06.124

4. Ji, Y. G., Li, C., North, M., \& Liu, J. (2017). Staking reputation on stakeholders: How does stakeholders' Facebook engagement help or ruin a company's reputation?. Public Relations Review, 43(1), 201-210. https://doi.org/10.1016/j.pubrev.2016.12.004

5. Manaman, H. S., Jamali, S., \& AleAhmad, A. (2016). Online reputation measurement of companies based on user-generated content in online social networks. Computers in Human Behavior, 54, 94-100. https://doi.org/10.1016/j.chb.2015.07.061

6. Rincon-Flores, E. G., Gallardo, K., \& Fuente, J. M. D. L. (2018). Strengthening an Educational Innovation Strategy: Processes to Improve Gamification in Calculus Course through Performance Assessment and Metaevaluation. International Electronic Journal of Mathematics Education, 13(1), 1-11. https://doi.org/10.12973/iejme/2692

7. Shlyapentokh, V. E. (1966). Econometrics and economic growth problems. - M.

8. Villalobos, J. V. (2018). Politics as a requirement. On the concept of Human Rights and the right to an autobiography as an ethical category. Opción, 34(85-2), 9-19.

9. Villalobos, J. V., Márceles, V., \& Ayala, T. (2013). Epistemología y Ciencia: La Hermenéutica Filosófica como crítica al Método Científico. REDHECS, 16(9), 105-120.

10. Savelyeva, N. K., Kuklin, A. V., Lapteva, I. P., \& Malysheva, N. V. (2019). The investment attractiveness of a regional market of educational services as the basis of its global competitiveness in industry 4.0. On the Horizon. https://doi.org/10.1108/OTH-07-2019-0042

11. Eidelman, B. M., Fakhrutdinova, L. R., \& Gabdrakhmanov, N. K. (2017). Territorial branding as an important factor of the steady increase of investment and tourist-recreational appeal of the region. Revista QUID, 1(1), 299304.

12. Simonova, M. V., Sankova, L. V., Mirzabalaeva, F. I., Shchipanova, D. Y., \& Dorozhkin, V. E. (2016). Assessment Problems and Ensuring of Decent Work in the Russian Regions. International Journal of Environmental and Science Education, 11(15), 7608-7626.

13. Pugacheva, A. S., Filippova, V. P., Kon, A. Y., Dorzhieva, L. B., Silchenok, I. S., Pugacheva, N. B., ... \& Mustafina, A. A. (2016). Market regulators of service spheres innovative development as a tool of regional socioeconomic policy. International Review of Management and Marketing, 6(2S), 294-300.

14. Kuznetsova, I. G., Voronkova, O. Y., Nimatulaev, M. M., Ruiga, I. R., Zhuruli, G. N., \& Levichev, V. E. (2019). Ensuring the national security of agriculture in the digital era through the formation of human capital.

15. Ermasova, N., Ijose, O., \& Ermasov, S. (2018). Regional patent activity in Russia: does level of risks make a difference?. Competitiveness Review: An International Business Journal, 28(2), $136-154$. https://doi.org/10.1108/CR-11-2016-0073

16. Gallyamova, D. K., \& Miftakhov, A. I. D. (2017). Boosting the autonomy of regional banking systems as a driver of economic development: The case of Russia. Regional Science Inquiry, 9(2), 55-68.

17. Edronova, V. N., \& Maslakova, D. O. (2019). THEORETICAL AND PRACTICAL ASPECTS OF EQUITY FINANCE OF INVESTMENT: SOURCES, FORMS, MECHANISMS, TOOLS. Дайджест-финансы, 24(3 (251)). https://doi.org/10.24891/df.24.3.244

18. Bazhenov, S. V., \& Bazhenova, E. Y. (2016). The Interrelation between the Economic Identity of the Region and its Brands. Moscow Economic Journal, 4.

19. Crescenzi, R., \& Jaax, A. (2017). Innovation in Russia: the territorial dimension. Economic Geography, 93(1), 6688. https://doi.org/10.1080/00130095.2016.1208532

20. Jaax, A. (2016). Essays on disparities in innovative performance and economic development in emerging countries: a regional and firm-level investigation (Doctoral dissertation, The London School of Economics and Political Science (LSE)). 